\title{
PENGARUH PERSEPSI NILAI ANAK TERHADAP GAYA PENGASUHAN PADA KELUARGA DENGAN ANAK USIA DINI
}

\author{
Kenty Martiastuti ${ }^{1}$ \\ 1Badan Akreditasi Nasional PAUD PNF Provinsi Jawa Barat, Bandung Barat 40391, Indonesia \\ *) E-mail: akre.kenty@gmail.com
}

\begin{abstract}
Abstrak
Penelitian ini bertujuan untuk mengidentifikasi nilai anak dan gaya pengasuhan yang diterapkan pada keluarga dengan anak usia dini serta menganalisis pengaruh nilai anak terhadap gaya pengasuhan. Penelitian ini dilakukan di dua lembaga PAUD di wilayah Kota Tangerang Selatan dan Kota Depok dengan responden sebanyak 61 orang. Data yang dikumpulkan dari penelitian ini adalah persepsi nilai anak (value of children) menggunakan dimensi yang dimodikasi dari Nauck (2014) dan gaya pengasuhan menggunakan instrumen Primary Caregivers Practices Report (PCPR) dari Robinson (1995). Hasil penelitian menunjukkan adanya perbedaan antara nilai psikologi dan nilai ekonomi pada anak laki-laki dan anak perempuan. Terlihat pula adanya pengaruh persepsi nilai anak terhadap gaya pengasuhan dengan $R^{2}=0,153$ dan signifikan pada taraf nyata 95 persen. Hal ini berarti bahwa semakin baik persepsi orang tua tentang nilai anak maka akan semakin baik pula gaya pengasuhan yang diterapkan. Persepsi nilai anak mempengaruhi gaya pengasuhan sebesar 15,3 persen dan selebihnya merupakan faktor lain.
\end{abstract}

Kata kunci: anak usia dini, gaya pengasuhan, nilai anak

\section{Influence of Children's Value Perception on Parenting Style In Families with Early Childhood Children}

\begin{abstract}
This study aims to identify the value of children and parenting styles that are applied to families with early childhood and analyze the influence of value of children on parenting style. This research was conducted in two early childhood institutions in the area of South Tangerang City and Depok City with 61 respondents. Data collected from this study are the perception of the value of children using a modified dimension from Nauck (2014) and parenting style using the Primary Caregivers Practices Report (PCPR) instrument from Robinson (1995). The results showed a difference between the psychological value of children and the economic value of children in boy and girl. Also seen is the effect of the perception of value of children on parenting style with $R^{2}=0.153$ and significant at 95 percent level. This means that the better the parent's perception of the value of children, the better parenting style that is applied. Perception of the value of children affects parenting style by 15.3 percent and the rest is another factor.
\end{abstract}

Keywords: early childhood children, parenting style, value of children

\section{PENDAHULUAN}

Usia dini merupakan masa emas, masa ketika anak mengalami pertumbuhan dan perkembangan yang pesat. Pada usia ini anak paling peka dan potensial untuk mempelajari sesuatu, rasa ingin tahu anak sangat besar. Pertumbuhan yang terjadi pada anak usia dini tidak hanya meliputi perubahan fisik, tetapi juga perubahan dan perkembangan dalam cara berpikir dan bertingkah laku yang berlangsung secara sistematis, progresif, dan berkesinambungan. Menurut Murni (2017), perkembangan biologis dan fisik di usia awal berjalan dengan sangat cepat dan pesat, akan tetapi secara sosiologisnya anakanak masih sangat terikat dengan lingkungannya terutama keluarga. Usia dini merupakan masa keemasan bagi seorang anak. Stimulasi atau rangsangan menjadi begitu penting untuk 
membuat anak dapat tumbuh kembang secara optimal. Hati dan Lestari (2016) mengemukakan bahwa stimulasi tumbuh kembang berhubungan signifikan dengan perkembangan anak. Stimulasi tumbuh kembang ini dapat bersumber dari lingkungan di sekitar anak. Pada anak usia dini, ada dua lingkungan terdekat anak yaitu lingkungan keluarga dan juga lingkungan sekolah. Hasil penelitian Elmanora, Hastuti, dan Muflikhati (2017) menunjukkan bahwa stimulasi dari lingkungan keluarga memiliki pengaruh yang lebih kuat dibandingkan dengan stimulasi dari lingkungan sekolah. Stimulasi dari lingkungan keluarga dapat diberikan melalui pengasuhan. Putra, Yudiemawati, dan Maemunah (2018) juga mengemukakan hal yang sama yaitu pemberian stimulasi oleh orang tua dapat meningkatkan perkembangan Bahasa anak usia toddler. Oleh karena itu, pengasuhan yang baik menjadi suatu hal yang sangat penting bagi perkembangan anak.

Menurut Brooks (2011), pengasuhan merupakan sebuah proses yang merujuk pada serangkaian aksi dan reaksi yang dilakukan orang tua untuk mendukung perkembangan anak. Proses pengasuhan merupakan proses dua arah antara orang tua-anak dan anak-orang tua yang juga dipengaruhi oleh kondisi sosial budaya dimana anak tersebut dibesarkan. Teori Vygotsky juga mengemukakan bahwa perkembangan anak sangat dipengaruhi oleh lingkungan sekitarnya. Perkembangan anak tidak serta merta terbentuk dalam situasi sosial yang hampa. Vigotsky menekankan bagaimana proses perkembangan mental seorang anak bergantung pada lingkungan sosial budaya masyarakat di sekitarnya terlebih lagi praktek pengasuhan yang diterapkan dalam keluarga sebagai lingkungan terdekatnya (Hastuti, 2015).

Anak merupakan investasi bagi orang tuanya. Oleh karena itu orang tua akan melakukan pengasuhan yang sesuai dengan harapan orang tuanya terhadap anaknya di masa yang akan datang. Hal ini sejalan dengan yang dikemukakan oleh Hoffman dan Hoffman (1973) bahwa nilai anak merupakan persepsi dan harapan orang tua terhadap anak berdasarkan potensi yang dimiliki anak.

Gelombang perubahan sosial budaya pada masyarakat yang semakin besar dapat membawa imbas kepada kehidupan keluarga sebagai unit terkecil yang berada dalam lingkaran masyarakat. Perubahan yang dirasakan bukan hanya terjadi pada sistem ekonomi, namun juga pada pergeseran nilai-nilai yang dianut. Pergeseran nilai-nilai budaya dalam keluarga dapat terlihat dari perubahan pola kehidupan keluarga dalam berbagai aspek. Pergeseran tersebut juga mempengaruhi secara mendasar hubungan orang tua dengan anak, termasuk di dalamnya persepsi orang tua terhadap kedudukan anak, apa yang diharapkan dari anak, serta karakter anak seperti apa yang ingin dibentuk oleh orang tua (Hurlock, 1997).

Penelitian tentang nilai anak (value of children) selama ini lebih banyak dikaitkan dengan kondisi sosial budaya setempat (Albert, et al, 2005; Kagitcibasi, et al, 2005; Nauck, 2000), ataupun jumlah anak yang diinginkan. Penelitian Bulatao dan Lee (1983) serta Shapiro (1997) dalam Hartoyo dkk (2011) menemukan bahwa persepsi orang tua terhadap nilai anak berpengaruh terhadap jumlah anak yang diinginkan (demand for children). Penelitian menunjukkan hubungan positif antara nilai anak dan jumlah anak yang diinginkan. Ketika anak dipersepsikan memiliki kegunaan dan manfaat yang besar maka orang tua menginginkan jumlah anak yang lebih banyak. Sebaliknya pada saat orang tua memiliki persepsi bahwa dengan memiliki anak yang banyak akan memiliki beban atau menanggung biaya yang lebih besar, maka orang tua menginginkan jumlah anak yang lebih sedikit (Shapiro, 1997 dalam Hartoyo, 2011) dan pada akhirnya hal ini akan berpengaruh pada keikutsertaan keluarga dalam program keluarga berencana (Hartoyo, 2011).

Begitu pula penelitian tentang faktor yang mempengaruhi gaya pengasuhan, lebih banyak dikaitkan dengan status sosial ekonomi, kondisi sosial budaya setempat atau kondisi kepribadian dan psikologis orang tua. Seperti penelitian yang dilakukan oleh Nam dan Chun (2014) yang menemukan bahwa gaya pengasuhan merupakan salah satu faktor paling signifikan untuk perkembangan anak, terutama untuk anak-anak dengan atau berisiko mengalami keterlambatan perkembangan. Karena pentingnya gaya pengasuhan, penelitian 
diarahkan untuk mengeksplorasi faktor-faktor yang mempengaruhi gaya pengasuhan dalam keluarga dengan anak-anak yang berisiko atau dengan keterlambatan perkembangan di Korea Selatan. Hasil penelitian menunjukkan bahwa pekerjaan ibu, usia ibu, stres orangtua, dan dukungan sosial secara signifikan terkait dengan gaya pengasuhan ibu (Nam \& Chun, 2014). Penelitian lain menemukan bahwa faktor-faktor yang mempengaruhi gaya pengasuhan adalah status mental, tingkat stres, kepribadian, trauma masa kecil, kepuasan pernikahan, penyalahgunaan obat-obatan terlarang, karakteristik ibu dan dukungan sosial. (Bahramil, 2017). Sementara ini belum ditemukan penelitian yang mengarah pada pengaruh persepsi nilai anak terhadap gaya pengasuhan yang dilakukan.

Oleh karena itu, berawal dari asumsi bahwa pengasuhan itu merupakan hal yang penting dalam perkembangan anak maka penelitian ini bertujuan untuk mengidentifikasi pengaruh persepsi nilai anak terhadap gaya pengasuhan pada keluarga dengan anak usia dini. Selain itu, penelitian ini juga akan menganalisis apakah terdapat perbedaan persepsi nilai anak berdasarkan jenis kelamin serta perbedaan pola asuh pada keluarga dengan anak usia dini berdasarkan jenis kelamin.

\section{METODE}

Desain penelitian adalah cross sectional study. Penelitian ini dilakukan di 2 Lembaga PAUD di wilayah Tangerang Selatan dan Depok. Pemilihan lokasi penelitian dilakukan secara Purposive Sampling karena kemudahan akses dan ketersediaan data yang memadai. Waktu pengambilan data akan dilakukan pada bulan Agustus - Oktober 2018.

Lembaga PAUD yang dijadikan tempat penelitian adalah lembaga AA di wilayah Tangerang Selatan dan lembaga IA di wilayah Depok. Responden adalah orang tua siswa (Ibu Kandung) dari siswa PAUD yang berusia $4-6$ tahun yang dipilih secara purposive, yaitu yang menerapkan gaya pengasuhan autoritatif, sehingga jumlah total responden dalam penelitian ini adalah 61 orang. Jenis data yang dikumpulkan adalah: (1) Karakteristik Keluarga (usia orang tua, besar keluarga, pendapatan orang tua, pendidikan orang tua, pekerjaan orang tua; (2) karakteristik contoh (usia dan jenis kelamin); (3) persepsi nilai anak (4) gaya pengasuhan

Persepsi Nilai Anak diukur dengan menggunakan instrument yang dikembangkan berdasarkan Nauck (2011) yaitu Value of Children (VOC) atau nilai anak yang terdiri dari nilai spiritual, nilai psikologis, nilai sosial dan nilai ekonomi. Nilai spiritual terdiri dari 7 item pertanyaan, nilai psikologis terdiri dari 6 item pertanyaan, nilai sosial terdiri dari 10 item pertanyaan dan nilai ekonomi terdiri dari 8 item pertanyaan. Jumlah total instrument nilai anak ada 31 item pertanyaan dengan nilai alpha cronbach sebesar 0.842 . Pola asuh anak usia dini menggunakan Primary caregivers Practices Report (PCPR). Skor dari PCPR (Robinson et al, 1995) menilai tingkat gaya pengasuhan orang tua yang mengacu pada pola asuh menurut Baumrind, yaitu otoriter (kontrol tinggi, kehangatan rendah), permisif (kontrol rendah, kehangatan tinggi) dan autoritatif (kontrol tinggi, kehangatan tinggi).

PCPR terdiri dari 52 item pertanyaan dimana orang tua menunjukkan seberapa sering menyatakan perilaku yang menunjukkan ketiga pola asuh tersebut ketika berinteraksi dengan anak-anak mereka. Sebanyak 17 item menunjukkan pola asuh otoriter, 11 item menunjukkan pola asuh permisif dan 24 item pertanyaan menunjukkan pola asuh autoritatif. Pilihan jawaban responden merupakan skala Likert yaitu sangat tidak setuju (STS), tidak setuju (TS), setuju (S) dan sangat setuju (SS).

Karena pola asuh/gaya pengasuhan dengan PCPR dikonseptualisasikan secara konstektual dan tidak saling eksklusif, skor dijumlahkan sebagai arahan bagi setiap orang tua pada masing-masing gaya pengasuhan. Semakin tinggi skor pada gaya pengasuhan tertentu, maka semakin besar kecenderungan orang tua tersebut dikatakan memiliki gaya pengasuhan tersebut. Jadi dapat saja orang tua memiliki skor otoritatif yang tinggi, skor permisif sedang dan skor otoriter rendah, tergantung dari praktik pengasuhan yang dilaporkannya. Ukuran pengasuhan otoriter adalah 0-68, pengasuhan permisif 0-44 dan pengasuhan otoritatif 0-96. 
Responden yang diambil adalah yang menerapkan gaya pengasuhan autoritatif karena sebagian besar (lebih dari 95 persen) populasi yang ada. Data yang diperoleh akan ditabulasi dan dianalisis meliputi data karakteristik contoh (usia dan jenis kelamin), persepsi nilai anak dan gaya pengasuhan. Untuk melihat hubungan antar variabel digunakan uji Pearson Correlation dan untuk melihat perbedaan variabel berdasarkan jenis kelamin anak digunakan uji beda Independent T-test. Pengolahan data dilakukan dengan SPSS 20.0.

\section{HASIL DAN PEMBAHASAN}

\section{Karakteristik Anak}

Jumlah keseluruhan responden adalah 61 orang yaitu ibu yang memiliki anak usia dini (46 tahun). Jumlah responden berdasarkan jenis kelamin anak adalah 33 orang (ibu dari anak laki-laki) dan 28 orang (ibu dari anak perempuan). Selanjutnya, penyebutan laki-laki dan perempuan adalah untuk menggambarkan jenis kelamin anak yang dimiliki oleh responden.

Tabel 1. Sebaran responden berdasarkan usia anak

\begin{tabular}{lcc}
\hline \multicolumn{1}{c}{ Usia Anak } & Jumlah & Persentase $(\%)$ \\
\hline 4 tahun & 17 & 27.9 \\
5 tahun & 28 & 45.9 \\
6 tahun & 16 & 26.2 \\
\hline
\end{tabular}

\section{Perbedaan Nilai Anak Berdasarkan Jenis Kelamin}

Kemajuan zaman seperti yang terjadi saat ini, sedikit banyak juga membawa perubahan pada pandangan terhadap nilai anak. Pada masa-masa dahulu, kedudukan anak laki-laki lebih tinggi dibandingkan dengan anak perempuan. Anak laki-laki dari sisi ekonomi memiliki fungsi mencari nafkah, sedangkan anak perempuan hanya bertugas mengurus keluarga di rumah. Perempuan dianggap tidak layak untuk bekerja dan memperoleh pendapatan, sehingga muncul anggapan bahwa laki-laki bertugas di luar rumah sedangkan perempuan bertugas di dalam rumah melakukan tugas-tugas domestik. Pada masa sekarang, seiring dengan adanya perubahan zaman, kedudukan anak laki-laki dan anak perempuan dianggap relatif sama. Akibatnya, tidak ada lagi pemisahan tugas dalam mencari nafkah keluarga (Nelli, 2017). Adanya perubahan terhadap pandangan anak laki-laki dan anak perempuan tersebut mengakibatkan keinginan keluarga untuk mendapatkan salah satu jenis kelamin menjadi hilang dan bergeser kepada kualitas kehidupan anak tersebut.

Pergeseran nilai-nilai budaya dalam keluarga dapat terlihat dari perubahan pola kehidupan keluarga dalam berbagai aspek. Pergeseran tersebut juga mempengaruhi secara mendasar hubungan orang tua dengan anak, termasuk di dalamnya persepsi orang tua terhadap kedudukan anak, apa yang diharapkan dari anak, serta karakter anak seperti apa yang ingin dibentuk oleh orang tua (Hurlock, 1997). Persepsi nilai anak juga dapat berbeda tergantung jenis kelamin anak. Sebagai contoh, pada masyarakat Batak, kehadiran anak lakilaki dalam sebuah keluarga akan meningkatkan status sosial keluarga tersebut. Anak laki-laki sangat diutamakan karena anak laki-laki adalah pembawa marga dan penerus keturunan pada keluarga masyarakat Batak Toba. Anak adalah kebanggaan didalam masyarakat Batak Toba. Anak pada masyarakat Toba juga sebagai penambah sahala (wibawa) bagi orangtua karena apabila tidak memiliki anak laki-laki maka garis keturunan pada keluarga tersebut akan punah (Sianturi, 2017).

Nilai anak secara psikologis atau nilai psikologis anak diartikan bahwa anak dapat menjadi sebuah sumber kepuasan bagi orang tuanya. Dari segi psikologis, tampaknya anak mempunyai nilai positif maupun negatif. Nilai psikologis yang positif dapat dilihat dari adanya kenyataan yang dialami oleh para orangtua bahwa anak dapat menimbulkan perasaan aman, 
terjamin, bangga dan puas. Perasaan semacam ini umumnya dialami oleh suami istri yang telah mempunyai anak laki-laki. Mereka merasa puas, aman dan terjamin karena yakin telah ada anak yang diharapkan menggantikannya kelak dalam melaksanakan kewajiban adat, di lingkungan kerabat maupun masyarakat. Selain itu, anak juga dirasakan dapat menghibur orang tuanya, memberi dorongan untuk lebih semangat bekerja, dan menghangatkan hubungan suami istri.

Nilai psikologis yang negatif dapat dilihat dari adanya kenyataan yang dialami oleh beberapa orangtua yang anaknya sering sakit, sehingga anaknya itu menimbulkan perasaan khawatir/was-was. Selain itu, ada juga kenyataan bahwa beberapa orangtua mengeluh setelah punya anak, karena merasa kurang bebas kalau akan pergi atau bekerja. Dalam hal seperti ini, anak dirasakan membuat hidupnya repot. Namun demikian, apabila dibandingkan ternyata lebih banyak orangtua yang merasakan bahwa anak mempunyai nilai positif dalam hidupnya (Prasanti, 2013).

Hasil penelitian ini menunjukkan skor rata-rata persepsi nilai psikologis anak pada lakilaki adalah 18,97, sedangkan pada anak perempuan adalah 19,82. Hal ini menunjukkan bahwa orang tua memiliki persepsi yang lebih tinggi dalam menilai anak perempuan dari sudut psikologis dibanding kepada anak laki-laki. Persepsi nilai anak secara psikologis dalam penelitian ini dapat dilihat antara lain orang tua merasa nyaman jika berada dekat anak, anak membawa kebahagiaan tersendiri bagi orang tua, dengan adanya anak akan menambah kasih sayang suami istri, orang tua tidak merasa lelah saat bermain dengan anak dan orang tua merasa senang berada dekat dengan anak. Perbedaan nilai anak secara psikologis signifikan antara laki-laki dan perempuan pada taraf nyata 90 persen.

Menurut Albert, et al. (2005) ada beberapa alasan ekonomi yang dimiliki orang tua untuk memiliki anak, antara lain untuk membantu keluarga secara ekonomi dan juga membantu pekerjaan di rumah. Hasil penelitian ini juga menunjukkan perbedaan yang signifikan pada nilai ekonomi anak berdasarkan jenis kelamin. Skor rata-rata pada anak laki-laki lebih tinggi daripada anak perempuan, yaitu 22,21 pada anak laki-laki dan 20,18 pada anak perempuan. Perbedaan ini signifikan pada taraf nyata 95 persen. Nilai ekonomi anak antara lain dapat dilihat dari beberapa indikator seperti anak dapat memberi bantuan ekonomi di hari tua, dengan memiliki anak maka kehidupan di hari tua akan ada yang menanggung dan anak dapat membantu keuangan keluarga jika sudah bekerja. Penelitian ini menunjukkan bahwa secara nilai ekonomis, anak laki-laki lebih dipersepsikan memiliki nilai ekonomi karena harapan orang tua, anak laki-laki kelak akan menjadi tulang punggung dan pencari nafkah dalam keluarga.

Nilai ekonomi anak merupakan nilai dimana anak memiliki nilai ekonomi yaitu sebagai investasi jangka panjang untuk meningkatkan ekonomi keluarga dimasa yang akan datang. Presepsi dan harapan orang tua pada anak berbeda di berbagai budaya. Anak merupakan sumberdaya yang utama dan berharga, anak merupakan representasi orang tua di masa depan. Secara alami orang tua menganggap anak merupakan nilai investasi yang paling efisien pada masa yang akan datang yang meliputi nilai psikologis dan nilai materi. Investasi yang ditanamkan orang tua pada anak diwujudkan dalam proses pengasuhan yang baik, perawatan, pendidikan di sekolah, dan pemenuhan gizi seimbang yang terdapat dalam menu makanan sehari-hari demi perkembangan anak yang maksimal.

Menurut Nurlaila (2017), nilai anak dalam segi spiritual dilandasi oleh adanya prinsip (utang) secara timbal-balik antara orangtua dan anak. Pembayaran utang tersebut dapat dilakukan dengan melaksanakan kewajiban satu terhadap yang lain. Pengorbanan orangtua terhadap anak mulai dilakukan sejak bayi masih didalam kandungan. Selain itu anak adalah anugerah dan titipan dari Tuhan yang harus dirawat dan dijaga. wajib menghormati dan menyenangkan orang tua semasa hidupnya. Sedangkan nilai anak dalam kehidupan sosial, tampak dalam hal anak berperan sebagai penerus keturunan dan sebagai ahli waris. Dalam peranannya sebagai ahli waris, anak tidak semata-mata mewarisi harta peninggalan orangtua (warisan yang bersifat material), akan tetapi juga mewarisi kewajiban adat (warisan yang 
bersifat immaterial), seperti halnya menggantikan orangtua dalam melakukan proses adat atau tradisi.

Hasil penelitian menunjukkan tidak adanya perbedaan signifikan dalam persepsi nilai anak secara sosial dan spiritual. Hal ini menunjukkan bahwa orang tua tidak memiliki perbedaan persepsi dalam nilai anak secara sosial dan spiritual pada anak laki-laki maupun pada anak perempuan. Anak laki-laki dan perempuan dipandang dapat membawa nama baik keluarga, dapat menjadi jalan untuk ibadah, memiliki rizki masing-masing dan juga merupakan amanah dari Sang Pencipta yang harus selalu dijaga. Hasil uji beda skor rata-rata persepsi nilai anak berdasarkan jenis kelamin dapat dilihat pada Tabel 2.

Tabel 2 Hasil Uji Beda Skor rata-rata Persepsi Nilai Anak Berdasarkan Jenis Kelamin

\begin{tabular}{ccccc}
\hline $\begin{array}{c}\text { Persepsi Nilai } \\
\text { Anak }\end{array}$ & Nilai Spiritual & Nilai Psikologis & Nilai Sosial & Nilai Ekonomis \\
Anak & Anak & Anak & Anak \\
\hline Laki-laki & 26,09 & 18,97 & 34,61 & 22,21 \\
Perempuan & 26,11 & 19,82 & 33,71 & 20,18 \\
Uji Beda & - & $0,056^{*}$ & - & $0,035^{\star *}$ \\
\hline
\end{tabular}

\section{Perbedaan Gaya Pengasuhan Berdasarkan Jenis Kelamin}

Hasil penelitian menunjukkan bahwa ada perbedaan skor rata-rata gaya pengasuhan antara anak laki-laki dan perempuan. Skor rata-rata gaya pengasuhan pada anak perempuan $(79,61)$ lebih tinggi daripada anak laki-laki $(76,52)$, namun perbedaan ini tidak signifikan secara statistik. Walaupun secara umum tidak terlihat perbedaan signifikan dalam gaya pengasuhan berdasarkan jenis kelamin, namun jika diuji lebih mendalam, ada beberapa indicator gaya pengasuhan yang memiliki perbedaan signifikan pada taraf nyata 95 persen seperti dapat dilihat pada Tabel 3. Perbedaan itu terlihat pada rasa simpati yang ditunjukkan orang tua saat anaknya terluka atau frustasi (bersedih) dimana orang tua dengan anak perempuan lebih menunjukkan rasa simpatinya dibanding kepada anak laki-laki. Hal ini kemungkinan disebabkan adanya anggapan bahwa anak laki-laki harus lebih kuat menghadapi kesulitan atau rasa sakit dibanding dengan anak perempuan.

Perbedaan signifikan juga terlihat pada saat orang tua memberitahu anaknya tentang apa yang ia harapkan untuk dilakukan sebelum melakukan suatu kegiatan. Dalam hal ini anak lakilaki memiliki skor yang lebih tinggi $(3,21)$ dibanding anak perempuan $(2,79)$. Selanjutnya perbedaan signifikan juga terlihat saat orang tua mengizinkan anaknya untuk ikut membuat aturan keluarga, dimana skor rata-rata pada anak perempuan lebih tinggi (2.54) dibanding skor rata-rata anak laki-laki $(1,94)$. Hal ini kemungkinan disebabkan karena anak perempuan lebih mudah untuk diajak berkomunikasi dibanding dengan anak laki-laki.

Penelitian serupa tentang perbedaan gaya pengasuhan berdasarkan jenis kelamin yang dilakukan oleh Stephens (2009) menemukan bahwa ada perbedaan yang signifikan di antara orang tua yang berinteraksi dengan anak-anak mereka yang laki-laki ataupun yang perempuan. Anak perempuan lebih dilindungi (bahkan cenderung over protective) terutama oleh ayahnya dibanding anak laki-laki. Hasil penelitian juga menemukan bahwa baik anak lakilaki maupun anak perempuan merasa lebih dekat pada ibu dibanding pada ayah.

Pengasuhan yang dilakukan secara positif dengan penuh kehangatan, perhatian, kasih sayang dan penerimaan akan mendukung terbentuknya karakter baik pada anak. Orang tua yang hangat, tetapi disiplin dan menetapkan peraturan yang dipahami anak akan menyebabkan anak cenderung berperilaku baik. Pengasuhan merupakan faktor eksternal lingkungan yang menyebabkan perubahan tingkah laku individu. Gaya pengasuhan autoritatif mendorong anak untuk mandiri, tetapi orang tua harus tetap menetapkan batas dan kontrol. Orang tua biasanya bersikap hangat, dan penuh welasasih kepada anak, bisa menerima alasan dari semua tindakan anak, mendukung tindakan anak yang konstruktif. Anak yang 
terbiasa dengan pola asuh otoritatif akan membawa dampak menguntungkan. Di antaranya anak akan merasa bahagia, mempunyai kontrol diri dan rasa percaya dirinya terpupuk, bisa mengatasi stres, punya keinginan untuk berprestasi dan bisa berkomunikasi, baik dengan teman-teman dan orang dewasa. Anak lebih kreatif, komunikasi lancar, tidak rendah diri, dan berjiwa besar (Hastuti, 2015).

Tabel 3 Skor rata-rata gaya pengasuhan berdasarkan jenis kelamin

\begin{tabular}{|c|c|c|}
\hline \multirow{2}{*}{ Indikator Pengasuhan Autoritatif } & \multicolumn{2}{|c|}{ Skor rata-rata } \\
\hline & Laki-laki & Perempuan \\
\hline $\begin{array}{l}\text { 1. Saya mendorong anak saya untuk berbicara tentang } \\
\text { masalah yang dihadapinya }\end{array}$ & 3,15 & 3,46 \\
\hline 2. Saya tahu nama-nama teman-teman anak saya & 3,24 & 3,43 \\
\hline $\begin{array}{l}\text { 3. Saya memuji anak saya ketika ia melakukan perbuatan } \\
\text { baik }\end{array}$ & 3,58 & 3,79 \\
\hline 4. Saya bermain dan bercanda dengan anak saya & 3,55 & 3,61 \\
\hline $\begin{array}{l}\text { 5. Saya menunjukkan rasa simpati ketika anak saya terluka } \\
\text { atau frustasi }\end{array}$ & 3,48 & 3,79 \\
\hline $\begin{array}{l}\text { 6. Saya berusaha memahami dan membuatnya nyaman } \\
\text { ketika anak saya marah }\end{array}$ & 3,00 & 3,29 \\
\hline 7. Saya bersikap santai pada anak saya & 2,79 & 2,86 \\
\hline $\begin{array}{l}\text { 8. Saya memberitahu anak saya tentang apa yang saya } \\
\text { harapkan ia lakukan sebelum melakukan suatu kegiatan }\end{array}$ & 3,21 & 2,79 \\
\hline 9. Saya bersabar dengan tingkah laku anak saya & 2,85 & 2,89 \\
\hline $\begin{array}{l}\text { 10. Saya segera menanggapi kebutuhan atau perasaan anak } \\
\text { saya }\end{array}$ & 3,45 & 3,39 \\
\hline $\begin{array}{l}\text { 11. Saya mengizinkan anak saya untuk ikut membuat aturan } \\
\text { keluarga }\end{array}$ & 1,94 & 2,54 \\
\hline $\begin{array}{l}\text { 12. Saya menjelaskan kepada anak saya mengapa aturan } \\
\text { harus dipatuhi }\end{array}$ & 3,33 & 3,50 \\
\hline $\begin{array}{l}\text { 13. Saya memberitahu anak saya bahwa ia dihargai atas apa } \\
\text { yang dilakukannya }\end{array}$ & 330 & 3,46 \\
\hline $\begin{array}{l}\text { 14. Saya mendorong anak saya untuk berbicara tentang hasil } \\
\text { pekerjaannya }\end{array}$ & 3,03 & 3,07 \\
\hline $\begin{array}{l}\text { 15. Saya mempertimbangkan keinginan anak saya sebelum } \\
\text { meminta mereka untuk melakukan sesuatu }\end{array}$ & 2,73 & 2,82 \\
\hline $\begin{array}{l}\text { 16. Saya selalu memperhatikan permasalahan anak saya di } \\
\text { sekolah }\end{array}$ & 3,36 & 3,64 \\
\hline $\begin{array}{l}\text { 17. Saya mengungkapkan kasih sayang kepada anak saya } \\
\text { dengan memeluk dan menciumnya }\end{array}$ & 3,70 & 3,82 \\
\hline 18. Saya meminta maaf kepada anak saya ketika saya salah & 3,70 & 3,75 \\
\hline $\begin{array}{l}\text { 19. Kadang saya membicarakan dengan anak saya tentang } \\
\text { kenakalan yang dilakukannya }\end{array}$ & 3,15 & 3,07 \\
\hline $\begin{array}{l}\text { 20. Saya punya waktu yang intim dan hangat dengan anak } \\
\text { saya }\end{array}$ & 3,42 & 3,57 \\
\hline $\begin{array}{l}\text { 21. Saya menjelaskan kepada anak saya bagaimana } \\
\text { perasaan saya tentang perilaku baik dan buruk yang ia } \\
\text { lakukan }\end{array}$ & 3,27 & 3,43 \\
\hline $\begin{array}{l}\text { 22. Saya sering berpikir tentang apa yang anak saya inginkan } \\
\text { dalam membuat rencana untuk keluarga }\end{array}$ & 2,85 & 3,14 \\
\hline $\begin{array}{l}\text { 23. Saya menjelaskan kepada anak saya konsekuensi dari } \\
\text { perilakunya yang kurang baik }\end{array}$ & 3,36 & 3,46 \\
\hline $\begin{array}{l}\text { 24. Saya menekankan berbagai alasan dalam peraturan yang } \\
\text { ditetapkan }\end{array}$ & 3,06 & 3,04 \\
\hline
\end{tabular}




\section{Pengaruh Persepsi Nilai Anak terhadap Gaya Pengasuhan}

Keluarga adalah tempat pertama anak melakukan interaksi sosial. Keluarga adalah salah satu lembaga tertua dan paling kuat di masyarakat. Walaupun memiliki struktur yang bervariasi, namun sebagian besar penelitian tentang keluarga, secara historis menemukan bahwa keluarga memiliki perspektif berbasis kekuatan yang memiliki kesamaan. Kesamaan menunjuk pada seperangkat kualitas yang menggambarkan karakteristik keluarga seperti adanya rasa kasih sayang dan menghargai, komunikasi positif, waktu yang menyenangkan bersama, kesejahteraan spiritual, dan kemampuan untuk mengelola stres dan krisis secara efektif (DeFrain \& Asay 2007). Oleh karena itu pengaruh keluarga sangat besar dalam membentuk dan mengembangkan karakter anak.

Banyak faktor yang mempengaruhi proses perkembangan anak. Diantara faktor yang mempengaruhi adalah praktek pengasuhan yang diterapkan orang tua. Hal tersebut dikuatkan oleh pendapat Duvall (1971) yang mengatakan bahwa keluarga adalah lingkungan yang pertama kali menerima kehadiran anak. Orang tua mempunyai berbagai macam fungsi yang salah satu di antaranya ialah mengasuh putra-putrinya. Dalam mengasuh anaknya orang tua dipengaruhi oleh budaya yang ada di lingkungannya. Di samping itu, orang tua juga diwarnai oleh sikap-sikap tertentu dalam memelihara, membimbing, dan mengarahkan putra-putrinya. Sikap tersebut tercermin dalam pola pengasuhan kepada anaknya yang berbeda-beda, karena orang tua mempunyai pola pengasuhan tertentu. Dalam hal ini, persepsi orang tua tentang nilai anak juga sedikit banyak akan mewarnai praktek pengasuhan yang akan diterapkan orang tua dalam keluarga.

Pola pengasuhan adalah pola interaksi antara anak dengan orangtua yang meliputi pemenuhan kebutuhan fisik (seperti makan, dan minum) dan kebutuhan non fisik seperti perhatian, empati, dan kasih sayang (Wibowo, 2007 diacu dalam Ayuningtyas, 2013). Dalam pengasuhan, lingkungan pertama yang berhubungan dengan anak adalah orangtua. Penelitian Ayuningtyas (2013) pada keluarga militer yang memiliki anak usia dini menunjukkan bahwa pedoman penanaman nilai dan norma berbeda pada setiap individu bertolak dari pola pengasuhan dalam keluarga. Setiap orangtua memberikan pola asuh tersendiri bagi keluarga mereka, karena setiap orangtua memiliki nilai- nilai tertentu yang dianggap sebagai nilai yang terbaik bagi keluarganya. Hal ini menunjukkan bahwa persepsi nilai anak yang dimiliki oleh orang tua akan memberikan pengaruh pada praktek pengasuhan yang dilakukannya.

Penelitian Cheah, Leung, Tahseen dan Schultz (2009) yang menunjukkan bahwa pengasuhan otoritatif memengaruhi penyesuaian diri anak dan hal ini diperantarai oleh kemampuan regulasi diri. Dengan kata lain, pengasuhan otoritatif mendorong terbentuknya regulasi diri pada anak yang kemudian memengaruhi secara negatif kemunculan perilaku bermasalah. Sementara itu, penelitian pada remaja di Indonesia menunjukkan bahwa orang tua yang menerapkan pengasuhan otoritatif dibandingkan dengan pengasuhan otoriter dan permisif cenderung memiliki anak dengan konsep diri yang lebih baik (Respati, Yulianto, \& Widiana, 2006) dan tingkat agresivitas yang lebih rendah (Saputra dan Sawitri, 2015). Penelitian lainnya menunjukkan bahwa pengasuhan otoritatif berhubungan secara positif dengan tingkat kejujuran dan tanggung jawab pada remaja (Pasaribu, Hastuti, \& Alfiasari, 2013). Jika dikaitkan dengan hasil-hasil penelitian tersebut, tentu gaya pengasuhan yang diterapkan sejak usia dini akan sangat mempengaruhi perkembangan anak sampai kelak dewasa.

Menurut Hurlock (1997) perubahan nilai anak akan menyebabkan perubahan pola asuh yang diterapkan orang tua pada anaknya. Pola asuh yang diterapkan orang tua akan sangat berpengaruh pada proses perkembangan anak. Cara orang tua merawat dan mengasuh anakanaknya akan bersifat permanen dan mendalam bagi kehidupan psikologis anak-anak pada tahap perkembangan selanjutnya. Hasil penelitian ini menunjukkan adanya pengaruh persepsi nilai anak terhadap gaya pengasuhan dengan $R^{2}$ sebesar 0,153 dan signifikan pada taraf nyata 95 persen. Hal ini berarti bahwa semakin baik persepsi orang tua tentang nilai anak 
maka akan semakin baik pula gaya pengasuhan yang diterapkan. Persepsi nilai anak memengaruhi gaya pengasuhan sebesar 15,3 persen dan selebihnya merupakan faktor lain. Sebagai pengasuh dan pembimbing dalam keluarga, orang tua sangat berperan dalam meletakkan nilai moral dan dasar-dasar perilaku bagi anak-anaknya. Landasan orang tua untuk melakukan sesuatu juga akan dipengaruhi oleh pola pikir dan persepsinya. Semakin baik persepsi orang tua terhadap nilai anak, tentu juga akan semakin baik pula orang tua menerapkan gaya pengasuhan pada anak-anaknya. Hal ini sejalan dengan pernyataan Guharja et al. (1992) bahwa secara umum, nilai adalah sesuatu yang dianggap baik, berguna, dan penting bagi seseorang. Juga sesuai dengan Deacon dan Firebaugh (1988) yang menyatakan bahwa nilai berkaitan dengan apa yang diinginkan atau dianggap berharga, menjadi kriteria utama dalam mencapai tujuan, sehingga menentukan keberlanjutan seluruh keputusan dan tindakan, termasuk tindakan dalam melakukan pengasuhan bagi anakanaknya.

Nilai anak dikonseptualisasikan sebagai konstruksi psikologis yang mengacu pada keuntungan yang diharapkan dari memiliki anak dan juga biaya serta kerugiannya. Secara spesifik, nilai anak dimaknai sebagai refleksi motivasi orang tua untuk memiliki dan membesarkan anak, dan di dalam motivasi tersebut termasuk juga tujuan personal dan pengalaman sosialisasi orang tua. Menurut Brooks (2011), pengasuhan merupakan kunci bagi perkembangan seorang anak. Pengasuhan yang orang tua terapkan kepada anak akan berbeda-beda antara orang tua satu dengan orang tua lainya. Orang tua dalam menggunakan gaya pengasuhan dipengaruhi oleh beberapa faktor.

Deacon dan Firebaugh (1988) menyatakan bahwa keluarga memiliki tanggung jawab dalam hal perawatan dan perkembangan dari anggota keluarga tersebut. Sebagai penghasil sumberdaya manusia, keluarga juga diharapkan untuk berfungsi dengan baik agar dapat menghasilkan sumberdaya manusia yang berkualitas. Investasi orang tua terhadap anak merupakan salah satu upaya yang dilakukan untuk menghasilkan sumberdaya manusia yang berkualitas, salah satunya melalui alokasi uang dan waktu untuk pendidikan dan kesehatan. Dengan demikian, motivasi orang tua untuk membesarkan anak dengan baik, dipengaruhi oleh persepsi orang tua tentang nilai anak. Hal ini terbukti dari hasil penelitian dimana persepsi nilai anak berhubungan secara signifikan dengan gaya pengasuhan.

\section{SIMPULAN DAN SARAN}

Hasil penelitian menunjukkan bahwa terdapat perbedaan dalam persepsi nilai anak berdasarkan jenis kelamin. Skor rata-rata persepsi nilai psikologis anak perempuan lebih tinggi dibanding anak laki-laki dan berbeda secara signifikan pada taraf nyata 90 persen. Sebaliknya, nilai ekonomis anak laki-laki lebih tinggi dibandingkan dengan anak perempuan dan berbeda secara signifikan pada taraf nyata 95 persen. Perbedaan juga ditemukan pada gaya pengasuhan antara anak laki-laki dan perempuan. Skor rata-rata gaya pengasuhan pada anak perempuan lebih tinggi daripada anak laki-laki, namun perbedaan ini tidak signifikan secara statistik. Hasil penelitian juga menunjukkan bahwa terdapat pengaruh persepsi nilai anak terhadap gaya pengasuhan. Hal ini berarti bahwa semakin baik persepsi orang tua tentang nilai anak maka akan semakin baik pula gaya pengasuhan yang diterapkan. Dengan demikian, orang tua sebaiknya memiliki persepsi yang baik mengenai anak. Orang tua yang memiliki persepsi yang baik ini akan mampu mengasuh, mendidik, dan merawat anak dengan baik.

\section{DAFTAR PUSTAKA}

Albert, I., Trommsdorff, G., Mayer, B and Schwarz. (2005). Value of Children in Urban and Rural Indonesia : Socio-Demographic Indicators, Cultural Aspects, and Empirical Findings. www.researchgate.net/publication/30014398. Diakses pada tanggal 20 Februari 2020 
Ayuningtyas, D. (2013). Orientasi Pola Pengasuhan Anak Usia Dini pada Keluarga Militer di Asrama KODAM Kelurahan Jatingaleh Candisari Semarang. Indonesian Journal of Early Childhood Education Studies, 2(2), 58-63. DOI: https://doi.org/10.15294/ijeces.v2i2.9242.

Bahramil, B., Dolatshahil, B., Pourshahbaz, A and Mohammadkhanil, P. (2017). Determinants of Authoritative Parenting Style in Iranian Mothers. Iranian Rehabilitation Journal, 15(4), 317-324.

Brooks, J. (2011). The process of parenting. Yogyakarta: Pustaka Pelajar.

Cheah, C. S. L., Leung, C. Y. Y., Tahseen, M., \& Schultz, D. 2009. Authoritative parenting among immigrant Chinese mothers of preschoolers. Journal Family Psychology, 23(3), 311-320. doi: 10.1037/a0015076.

Deacon, R. E., \& Firebaugh, F. M. (1988). Family Resources Management Principles and Aplication. Boston: Allyn and Bacon Inc.

Defrain, J., \& Asay, S. (2007). Strong Families around The World. Family Matters Journals, $53,8-13$.

Duvall, E. M. (1971). Family Development: Fourth Edition. Toronto: JB Lippincott Company.

Elmanora, Hastuti, D., \& Muflikhati, I. (2017). Lingkungan keluarga sebagai sumber stimulasi utama untuk perkembangan kognitif anak usia prasekolah. Jurnal IImu Keluarga \& Konsumen, 10(2), 143-156. https://doi.org/10.24156/jikk.2017.10.2.143.

Hartoyo, Latifah, M., \& Mulyani, S. R. (2011). Studi Nilai Anak, Jumlah Anak yang Diinginkan dan Keikutsertaan Orang Tua dalam Program KB. Jurnal Ilmu Keluarga dan Konsumen, 4(1), 37-45.

Hastuti, D. (2015). Pengasuhan: teori, prinsip dan aplikasinya di Indonesia. Bogor: IPB Press.

Hati, F. S., \& Lestari, P. (2016). Pengaruh Pemberian Stimulasi pada perkembangan anak usia 12-36 bulan di Kecamatan Sedayu, Bantul. Jurnal Ners dan Kebidanan Indonesia, 4(1), 44-48. DOI: http://dx.doi.org/10.21927/jnki.2016.4(1).44-48.

Hurlock, E. B. (2012). Psikologi Perkembangan Edisi Kelima. Jakarta: Penerbit Erlangga.

Hoffman, L. W., \& Hoffman, M. L. (1973). The value of children to parents. In 1. T Fawcett (Ed.), Psychological perspectives on population (pp. 19-76). New York: Basic Books

Kagitcibasi, C., \& Ataca, B. (2005). Value of Children and Family Change: A ThreeDecade Portrait from Turkey. Applied Psychology: An International Review, 54(3), 317-337

Nelli, J. (2017). Analisis tentang kewajiban nafkah keluarga dalam pemberlakuan harta bersama. Al Istinbath : Jurnal Hukum Islam, 2(1), 29-46.

Mc Cubbin. H.I., \& Thompson. (1987). Family Assessment Inventories for Research and Practice. Madison: The University of Wisconsin-Madison.

Murni. (2017). Perkembangan fisik, kognitif, dan psikososial pada masa kanak-kanak awal 26 tahun. Jurnal Ar-Raniry, 3(1), 19-33.

Nam, S. H., \& Chun, J. S. (2014). Influencing Factors on Mother's Parenting Style of Young Children at Risk for Developmental Delay in South Korea: The Mediating Effects of Parenting Stress. Children and Youth Services Review, 36, 81-89

Nauck, B. (2000). The Changing Value of Children - a Special Action Theory of Fertility Behavior and Intergenerational Relationship in Cross-Cultural. www.researchgate.net/publication/260479194. Diakses 10 Januari 2020.

Nurlaila. (2017). Interaksi keluarga terhadap konsep nilai anak pada masyarakat Betawi. Jurnal Kesejahteraan Keluarga dan Pendidikan, 4(1), 21-26. DOI: http://doi.org/10.21009/JKKP.041.04 
Pasaribu, R., Hastuti, D., \& Alfiasari, A. (2013). Gaya pengasuhan permisif dan rendahnya sosialisasi nilai dalam keluarga berisiko terhadap penurunan karakter remaja. Jurnal IImu Keluarga dan Konsumen, 6(3), 163-171. doi: 10.24156/jikk.2013.6.3.163

Prasanti, M. D. (2013). Nilai anak pada ibu dengan status social ekonomi tinggi ditinjau dari etnis Jawa. Calyptra: Jurnal IImiah Mahasiswa Universitas Surabaya, 2(1), 1-15.

Putra, A. Y., Yudiemawati, A., \& Maemunah, N. (2018). Pengaruh pemberian stimulasi oleh orang tua terhadap perkembangan bahasa pada anak usia toddler di Paud Asparaga Malang. Nursing News, 3(1), 563-571.

Respati, W. S., Yulianto, A., \& Widiana N. (2006). Perbedaan konsep diri antara remaja akhir yang mempersepsi pola asuh orang tua authoritarian, permissive dan authoritative. Jurnal Psikologi, 4(2), 119-138.

Robinson, C., Mandleco, B., Olsen, S. F., \& Hart, C. H. (1995). Authoritative, authoritarian, and permissive parenting practices: Development of a new measure. Psychological Reports, $77,819-830$

Saputra, D. K., \& Sawitri, D. R. (2015). Pola asuh otoriter orang tua dan agresivitas pada remaja pertengahan di SMK Hidayah Semarang. Jurnal Empati, 4(4), 320-326.

Sianturi, J. N. 2017. Makna Anak Laki-laki di Masyarakat Batak Toba (Studi kasus di Kota Sidikalang Kabupaten Dairi Provinsi Sumatera Utara). JOM FISIP, 4(2), 1-14.

Stephens, M. A. (2009). Gender Differences in Parenting Styles and Effects on The Parent Child Relationship. Thesis. Texas State University 